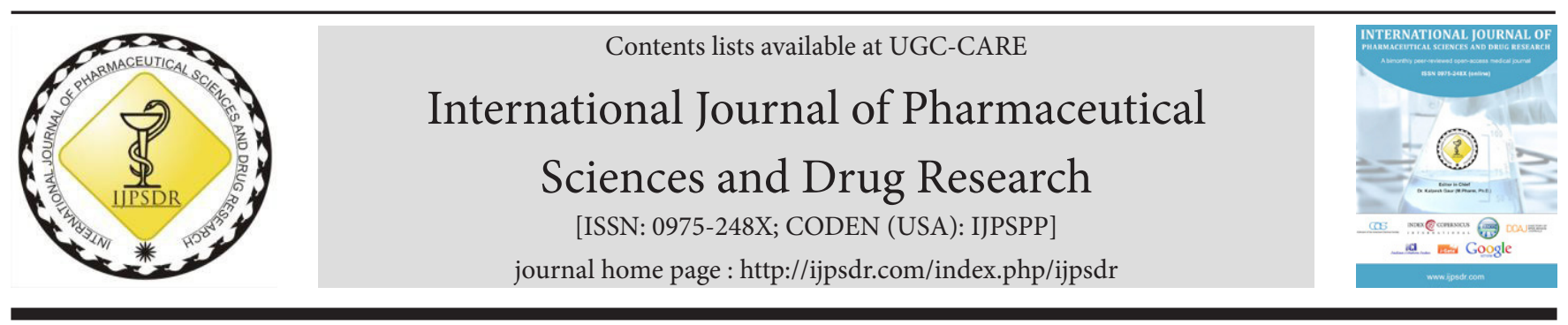

Research Article

\title{
Development of UV-spectrophotometric Method and its Validation for Estimating Contents of Prulifloxacin in Simulated Intestinal Fluid
}

\author{
K. Kumar*, Sobhna Singh \\ Department of Pharmacy, Mahatma Jyotiba Phule Rohilkhand University, Bareilly-243006, Uttar Pradesh, India
}

\begin{tabular}{|c|c|}
\hline ART ICLE INFO & A B S T R A C T \\
\hline $\begin{array}{l}\text { Article history: } \\
\text { Received: } 04 \text { October, } 2019 \\
\text { Revised: } 05 \text { January, } 2020 \\
\text { Accepted: } 20 \text { January, } 2020 \\
\text { Published: } 30 \text { January, } 2020 \\
\text { Keywords: } \\
\text { Fluoroquinolone, } \\
\text { Prulifloxacin, } \\
\text { Quantitative determination, } \\
\text { UV-spectrophotometric, } \\
\text { Validation. } \\
\text { D0I: } \\
\text { 10.25004/IJPSDR.2020.120103 }\end{array}$ & $\begin{array}{l}\text { This study was performed with the objective of developing and validating a UV-spectroscopic method } \\
\text { for estimating contents of prulifloxacin in simulated intestinal fluid (SIF), i.e., phosphate-buffer media } \\
\text { with a pH of } 6.8 \text { as per ICH guidelines. The } \lambda \text { max for prulifloxacin in phosphate-buffer media pH } 6.8 \\
\text { was found to be } 272 \text { nanometers. The calibration curve of the drug followed linearity in-between } \\
1-9 \mu \mathrm{g} / \mathrm{mL} \text { concentration range, and the correlation coefficient value was found equal to } 0.9995 \text {. We } \\
\text { tested this proposed method onto the bulk and marketed pharmaceutical formulation (tablets) also to } \\
\text { find out the contents of drugs. Using a developed method for estimation of prulifloxacin in simulated } \\
\text { intestinal fluid (SIF), the drug was found to be in-between } 101.91 \text { and } 104.02 \% \text { in marketed tablets, } \\
\text { which shows a good agreement with that of the claimed level. Accuracy of the developed method was } \\
\text { established through recovery experimentation, performed for three spiked percent concentrations- } 75 \text {, } \\
100 \text {, and } 125 \% \text {. The percentage recovery was found to be in between } 97.27 \text { and } 101.82 \% \text {. Low values of } \\
\text { percentage RSD supported accuracy as well as the reproducibility of a developed method. The precision } \\
\text { of the developed method was established by good in-limit intraday and interday experimental variations } \\
\text { and through repeatability tests. Values of } \% \text { relative standard deviation (RSD) less than two confirmed the } \\
\text { precision of a developed method. The ruggedness of the developed method was validated by performing } \\
\text { drug estimation by two different performers. This proposed spectroscopic method has proved to be a rapid } \\
\text { and successful method for routine analysis of prulifloxacin in simulated intestinal fluid. }\end{array}$ \\
\hline
\end{tabular}

\section{INTRODUCTION}

Prulifloxacin ${ }^{[1,2]}$ (Fig. 1): "6-Fluoro-1-methyl-7-[4-[(5methyl-2-oxo-1, 3-dioxol-4-yl) methyl]-1-piperazinyl]4-oxo-1H,4H-[1,3] thiazeto[3,2-a]quinoline-3-carboxylic acid" is a potent orally active 4 th generation fluoroquinolone antibiotic. It is a prodrug of ulifloxacin, which has a promising in-vitro and in-vivo antibacterial effect against a wide variety of gram (-)ve and gram (+)ve microorganisms causing chronic bronchitis, urinary tract infection, lower respiratory tract infections. ${ }^{[3-5]}$ It shows antibacterial activity by inhibiting the enzyme DNA gyrase and thereby preventing DNA replication and synthesis. ${ }^{[6]}$

To date, several analytical methods for quantification of prulifloxacin in bulk and pharmaceutical preparations have been proposed. Such methods may include UV-spectrophotometric methods for five different media ${ }^{[7]}$ HPLC, ${ }^{[8]}$ RP-HPLC, ${ }^{[9]}$ etc. However, just because of simplicity, economy, specificity, and easy availability, spectrophotometry has always been a method of preference among researchers for the estimation of various drugs. Previously it was assumed that the $\mathrm{pH}$ of<smiles></smiles>

Fig 1: Chemical structure of prulifloxacin

\footnotetext{
*Corresponding Author: Mr. K. Kumar

Address: Department of Pharmacy, Mahatma Jyotiba Phule Rohilkhand University, Bareilly-243006, Uttar Pradesh, India

Email $\bowtie$ : saxena_kaushal@yahoo.co.in, saxenakaushal11@gmail.com

Relevant conflicts of interest/financial disclosures: The authors declare that the research was conducted in the absence of any commercial or financial relationships that could be construed as a potential conflict of interest.

Copyright (C) 2020 K. Kumar et al. This is an open access article distributed under the terms of the Creative Commons Attribution- NonCommercialShareAlike 4.0 International License which allows others to remix, tweak, and build upon the work non-commercially, as long as the author is credited and the new creations are licensed under the identical terms.
} 
SIF is 7.5, which is very close to blood plasma. However, subsequent studies revealed that this $\mathrm{pH}$ is found in terminal ileum only. In contrast, drug absorption in the intestine is most efficient when a dosage form releases the drug at the proximal small intestine. Therefore, the $\mathrm{pH}$ of SIF should be equal to the $\mathrm{pH}$ of duodenum and proximal jejunum, which is 6.8. ${ }^{[10]}$ To avoid false-positive results, USP 24/ NF $19^{[11]}$ has revised the $\mathrm{pH}$ of SIF to 6.8, a typical $\mathrm{pH}$ of mid-jejunum. The work presented here was done to develop and validate a UV spectroscopic method, as per ICH guidelines, for estimating contents of prulifloxacin in phosphate-buffer-media-pH 6.8 which is simulatory to intestinal fluid. The present piece of work has resulted in a reliable method for the quantitative determination of prulifloxacin in SIF by UV spectrophotometer.

\section{Materials And Methods}

We performed this spectroscopic study on 1601 series model UV-Visible Double Beam Spectrophotometer by Shimadzu, Japan. A $1 \mathrm{~cm}$ quartz cuvette was used for obtaining absorption spectra and absorbances of reference and test solutions. Crude drug sample of prulifloxacin was procured from Hetero Labs Ltd. and was used as the reference standard. Tablets of prulifloxacin-600 mg- "Percin" by Lupin Ltd. were procured from the local market. Other analytical grade reagents and chemicals were arranged from laboratories and stores of university departments.

\section{Method development and optimization}

Prulifloxacin has poor aqueous solubility. During method development, few milliliters of Acetonitrile were used to dissolve the drug in SIF. Accurately weighed $10 \mathrm{mg}$ of prulifloxacin were dissolved in $5 \mathrm{~mL}$ of Acetonitrile and diluted with phosphate-buffer-media of $\mathrm{pH} 6.8$ through shaking for 15 minutes, and then the volume was made to $100 \mathrm{~mL}$. This concentrated solution was diluted 10 times to prepare the stock solution $(10 \mu \mathrm{g} / \mathrm{mL})$ of prulifloxacin. The $\lambda$ max for prulifloxacin was determined by scanning appropriate volumes of $5 \mu \mathrm{g} / \mathrm{mL}$ and $10 \mu \mathrm{g} / \mathrm{mL}$ solutions of prulifloxacin in SIF using UV-spectrophotometer in the scanning ranges of 200-400nm using SIF as blank. Different aliquots were taken from stock solution and diluted with SIF to get concentrations 1, 2, 3, 4, 5, 6, 7, 8, 9 and $10 \mu \mathrm{g} / \mathrm{mL}$, respectively. UV absorbances for these samples were observed at the $\lambda$ max using SIF as blank. The experiment was performed in triplicate, and averages were calculated, and calibration curves were plotted.

\section{Validation of Developed Method}

Validation of a developed method was done through determining linearity and linearity-range, accuracy, preciseness, specificities, ruggedness, and robustness according to ICH guidelines. ${ }^{[12,13]}$

\section{Linearity and Range}

To find out the concentration-range over which the drug solutions of prulifloxacin in SIF show the absorbance as a linear function of concentration, absorbances of 1 to $10 \mu \mathrm{g} / \mathrm{mL}$ solutions of drug in SIF were observed on UV spectrophotometer at $\lambda$ max. Absorbance for each concentration was observed three times, and averages were calculated. Calibration curves for different ranges of concentrations were plotted. All readings above 1 absorbance were excluded. Regression equations and regression coefficients were determined to study linearity.

\section{Accuracy}

Recovery tests were carried out to test the level of accuracy of the proposed analytical method. Under this study equal volumes of standard solutions $(10,12$ and $14 \mu \mathrm{g} / \mathrm{mL}$ respectively) were added to the equal volumes of preanalyzed samples ( $4 \mu \mathrm{g} / \mathrm{mL})$ so as to produce spiking of 75 , 100 , and $125 \%$. These concentration-spiked samples were reanalyzed for absorbances using the developed method. The recovery study was performed three times for each addition. Percentage recovery and percentage RSD were calculated.

\section{Precision}

A precision of the proposed method was ascertained through estimation of intraday and interday variations. For determining intraday preciseness of the developed method $-4,6$ and $8 \mu \mathrm{g} / \mathrm{mL}$ solutions of prulifloxacin were analyzed six times in a single day. For determining Interday preciseness 4,6 and $8 \mu \mathrm{g} / \mathrm{mL}$ of prulifloxacin solutions were analyzed on three different days by developed method. Average concentrations and \% RSD were calculated for estimating precision.

\section{Ruggedness}

Samples of $8 \mu \mathrm{g} / \mathrm{mL}$ concentrations were analyzed under similar environmental and operational conditions by two different analysts for determining ruggedness.

\section{Repeatability}

Repeatability of developed method has been confirmed through analyzing $4 \mu \mathrm{g} / \mathrm{mL}$ of prulifloxacin solution for at least six times.

\section{Estimation of Contents in Prulifloxacin-bulk}

$10 \mathrm{mg}$ of prulifloxacin were weighed accurately and dissolved in $5 \mathrm{~mL}$ of Acetonitrile and then diluted with phosphate-buffer media-pH 6.8 by shaking. Then volume was made up to $100 \mathrm{~mL}$. Then its $1.0 \mathrm{~mL}$ was diluted up to $20 \mathrm{~mL}$ using SIF. Absorbance of resulting solution ( $5 \mu \mathrm{g} / \mathrm{mL}$ ) was observed at $\lambda$ max taking SIF as blank. Concentration was calculated from linear regression equation. This procedure was performed six times and standard deviations and \% RSD value were calculated. 
UV spectroscopic method for estimating contents of Prulifloxacin in SIF

Table 1: Absorbance values and statistical data of the clibration curve

\begin{tabular}{lllllll}
\hline Concentra $^{n}(\mu \mathrm{g} / \mathrm{mL})$ & $A b 1$ & $A b 2$ & $A b 3$ & Mean & Std. Dev. & \%RSD \\
\hline 1 & 0.119 & 0.114 & 0.11 & 0.114333 & 0.004509 & 3.94395 \\
2 & 0.216 & 0.223 & 0.235 & 0.224667 & 0.009609 & 4.277013 \\
3 & 0.354 & 0.326 & 0.334 & 0.338 & 0.014422 & 4.266925 \\
4 & 0.468 & 0.452 & 0.442 & 0.454 & 0.013115 & 2.888739 \\
5 & 0.575 & 0.576 & 0.564 & 0.571667 & 0.006658 & 1.164722 \\
6 & 0.674 & 0.672 & 0.657 & 0.667667 & 0.009292 & 1.391649 \\
7 & 0.784 & 0.796 & 0.765 & 0.781667 & 0.015631 & 1.999723 \\
8 & 0.881 & 0.894 & 0.881 & 0.885333 & 0.007506 & 0.847766 \\
9 & 0.987 & 0.976 & 0.996 & 0.986333 & 0.010017 & 1.015544 \\
\hline
\end{tabular}

Abs stands for absorbance

SD for $\mathrm{n}=3$ observations.

\section{Estimation of Prulifloxacin in Tablets}

20 tablets of prulifloxacin-600 mg were powdered finely and powder-contents equivalent to $10 \mathrm{mg}$ of prulifloxacin were transferred in a $100 \mathrm{~mL}$ volumetric flask. This was first dissolved in $5 \mathrm{~mL}$ of acetonitrile by shaking for 15 minutes and then sufficient volume of SIF was added and shaken again for 5 minutes. Undissolved excipients were filtered out using whatman filter paper-42 and volume was made to $100 \mathrm{~mL}$ using SIF. This solution was then diluted 20 times again using SIF. Absorbance of the resulting solution was noted at $\lambda$ max taking SIF as blank. The concentration was back calculated from linear regression equation. Experiment was performed in triplicate and the average and \%RSD value were calculated.

\section{RESULTS}

\section{Method Development and Optimization}

The $\lambda$ max for prulifloxacin in SIF was found to be $272 \mathrm{~nm}$. Data for calibration curves are given in Table 1. Standard deviations for slope, intercept and regression coefficient were calculated using three individual calibration curves. The calibration curve of average absorbance for each concentration was set as optimized standard curve.

\section{Validation of Developed Method}

Validation of the developed method was done according to ICH guidelines by performing procedures given under the materials and methods.

\section{Linearity Studies}

Equation of linear regression for the developed method came out as $\mathrm{y}=0.1101 \mathrm{x}+0.0069$ for concentrations

Table 2: Linearity Parameters

\begin{tabular}{ll}
\hline Parameters & Values \\
\hline$\lambda \max$ & $272 \mathrm{~nm}$ \\
Linearity range $(\mu \mathrm{g} / \mathrm{mL})$ & $1-9 \mu \mathrm{g} / \mathrm{mL}$ \\
Regression equation & $\mathrm{y}=0.1101 \mathrm{x}+0.0069$ \\
Regression coefficient $\pm \mathrm{SD}$ & $0.9995 \pm 0.000577$ \\
Slope $\pm \mathrm{SD}$ & $0.1101 \pm 0.000577$ \\
Intercept $\pm \mathrm{SD}$ & $+0.0069 \pm 0.004041$ \\
\hline
\end{tabular}

SD for $\mathrm{n}=3$ observations. between 1 to $9 \mu \mathrm{g} / \mathrm{mL}$. Regression coefficient value was found to be $0.9995 \pm 0.000577$ for average calibration curve. The results have been shown in Table 2. The linearity curve of prulifloxacin has been presented in Fig. 2.

\section{Accuracy}

Under recovery studies for accuracy testing, \% recoveries and their standard deviations from the reanalysis of spiked drug solutions are given in Table 3.

\section{Precision}

Through intraday and interday studies for preciseness, average concentrations and \% RSD were calculated. $\%$ RSD values were found to $1.009,1.267,0.93 \%$ for intraday studies and 1.271, 1.066, 1.311\% for inter-day studies for $4,6,8 \mu \mathrm{g} / \mathrm{mL}$ concentrations of prulifloxacin solutions. The results have been shown in Table 4 .

\section{Ruggedness}

The results obtained by two different analysts adopting the same proposed method for estimation of prulifloxacin in SIF have are shown in Table 5. Calculated \% RSD was found to be $1.143 \%$.

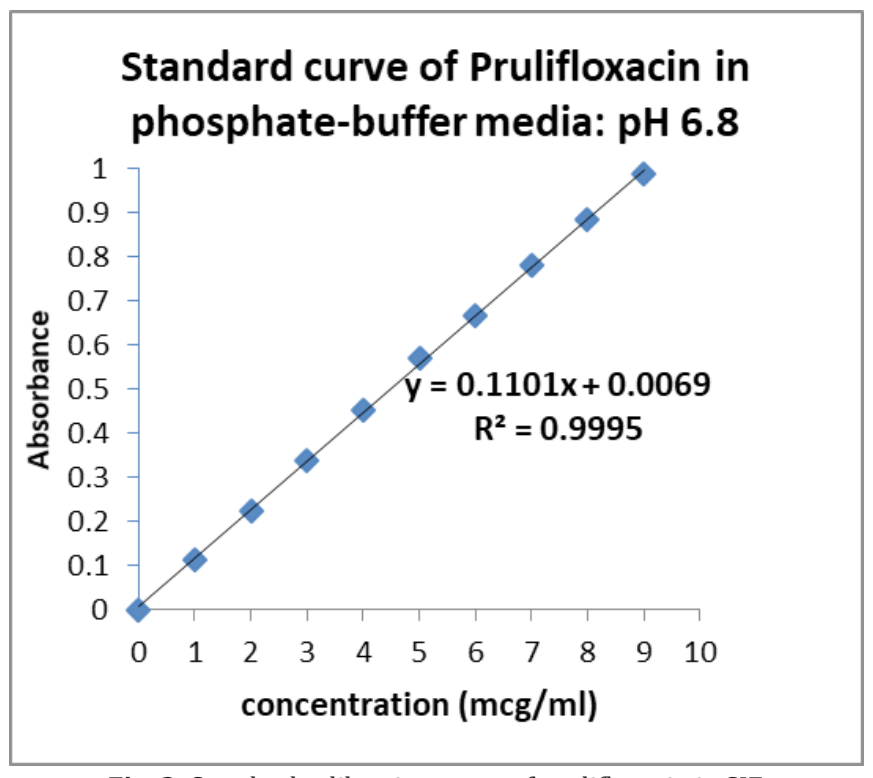

Fig. 2: Standard calibration curve of prulifloxacin in SIF. 
K. Kumar et al.

Table 3: Recovery studies

\begin{tabular}{|c|c|c|c|c|c|c|}
\hline \multirow{2}{*}{$\begin{array}{l}\text { Test } \\
\text { conc. }(\mu \mathrm{g} / \mathrm{mL})\end{array}$} & \multicolumn{2}{|c|}{ Spiked amount } & \multirow{2}{*}{$\begin{array}{l}\text { Final amount } \\
(\mu \mathrm{g} / \mathrm{mL})\end{array}$} & \multirow{2}{*}{$\begin{array}{l}\text { Recovered amount } \\
(\mu \mathrm{g} / \mathrm{mL})\end{array}$} & \multirow{2}{*}{$\begin{array}{l}\% \\
\text { recovery }\end{array}$} & \multirow{2}{*}{$\begin{array}{l}\% \\
R S D\end{array}$} \\
\hline & $\%$ & $(\mu g / m L)$ & & & & \\
\hline \multirow[t]{3}{*}{4} & 75 & 7 & 6.963636 & 2.963636 & 98.78788 & 1.547217 \\
\hline & & 7 & 7.027273 & 3.027273 & 100.9091 & \\
\hline & & 7 & 7.054545 & 3.054545 & 101.8182 & \\
\hline \multirow[t]{3}{*}{4} & 100 & 8 & 7.927273 & 3.927273 & 98.18182 & 1.601163 \\
\hline & & 8 & 8.054545 & 4.054545 & 101.3636 & \\
\hline & & 8 & 7.981818 & 3.981818 & 99.54545 & \\
\hline \multirow[t]{3}{*}{4} & 125 & 9 & 8.863636 & 4.863636 & 97.27273 & 1.583897 \\
\hline & & 9 & 9.018182 & 5.018182 & 100.3636 & \\
\hline & & 9 & 8.963636 & 4.963636 & 99.27273 & \\
\hline
\end{tabular}

Concentration level used for ruggedness study was $4 \mu \mathrm{g} / \mathrm{mL} .75,100$, and 125\% spiking in concentration was done by adding equal volumes of prulifloxacin solutions of 10,12 , and $14 \mu \mathrm{g} / \mathrm{mL}$ concentrations respectively.

Table 4: Precision studies

\begin{tabular}{llllll}
\hline & Concentration & \multicolumn{3}{c}{ Intraday precision $(\mathrm{N}=6)$} & \multicolumn{2}{c}{ Interday precision $(\mathrm{N}=3)$} \\
\cline { 2 - 5 } S. No. & $($ in $\mu \mathrm{g} / \mathrm{mL})$ & Average conc. & $\%$ Average conc. found & $\%$ RSD \\
\hline 1. & 4 & 3.977273 & 1.009344 & 3.981818 & 1.271179 \\
2. & 6 & 6.030303 & 1.267288 & 5.987879 & 1.066362 \\
3. & 8 & 7.998485 & 0.930098 & 7.978788 & 1.310705 \\
\hline
\end{tabular}

$\mathrm{n}=6$ (6 samples) for intra-day variation and $\mathrm{n}=3$ (3 samples each) on three different days.

Table 5: Ruggedness studies

\begin{tabular}{llllll}
\hline Analyst & S. No. & Conc. $(\mu \mathrm{g} / \mathrm{mL})$ & Conc. found & Average conc. & $\%$ RSD \\
\hline \multirow{3}{*}{1} & 1. & 8 & 7.872727 & 7.978788 \\
& 2. & 8 & 8.081818 & 1.142611 \\
2 & 3. & 8 & 7.981818 & \\
& 1. & 8 & 8.018182 & 7.957576 \\
\hline
\end{tabular}

Concentration level used by each analyst for ruggedness study was $8 \mu \mathrm{g} / \mathrm{mL}$.

\section{Repeatability}

Repeatability results are shown in Table 6. \%RSD was found to be $0.954 \%$.

Table 6: Repeatability studies

\begin{tabular}{llll}
\hline S. No & Conc. $(\mu \mathrm{g} / \mathrm{mL})$ & Conc. found & $\% R S D$ \\
\hline 1. & 4 & 3.990909 & \\
2. & 4 & 4.009091 & \\
3. & 4 & 3.927273 & 0.954002 \\
4. & 4 & 3.954545 & \\
5. & 4 & 4.009091 & \\
6. & 4 & 4.027273 & \\
\hline
\end{tabular}

Concentration level used for repeatability study was $4 \mu \mathrm{g} / \mathrm{mL} .(\mathrm{n}=6)$

Table 7: Estimation of prulifloxacin in bulk

\begin{tabular}{llll}
\hline S. No & Concentration $(\mu \mathrm{g} / \mathrm{mL})$ & Conc. found & \%RSD \\
\hline 1. & 5 & 4.954545 & 1.367697 \\
2. & 5 & 5.072727 & \\
3. & 5 & 5.009091 & \\
4. & 5 & 5.072727 & \\
5. & 5 & 5.090909 & \\
6. & 5 & 4.927273 & \\
\hline
\end{tabular}

$\%$ RSD stands for percentage relative standard deviation.
Estimation of Prulifloxacin in Bulk

Results are shown in Table 7. The \% RSD was found to be $1.3677 \%$.

\section{Estimation of Prulifloxacin in Tablets}

The percentage of claimed amounts in tablets was found to be in between 101.91 and $104.02 \%$ and the \%RSD for the proposed method has been found as $1.03 \%$. The results have been shown in Tables 8 and 9.

\section{DISCUSSION}

Standard calibration curve (drawn between average absorbances obtained from triplicate experiment for each concentration) has shown an excellent linearity in

Table 8: Estimation of prulifloxacin In tablets

\begin{tabular}{|c|c|c|c|c|}
\hline \multirow{2}{*}{$\begin{array}{l}\text { S. } \\
\text { No. }\end{array}$} & \multicolumn{2}{|c|}{ Amount of Drug $(\mathrm{mg} / \mathrm{tab})$} & \multirow[b]{2}{*}{$\%$ of claimed } & \multirow[b]{2}{*}{$\% R S D$} \\
\hline & Labeled & Estimated & & \\
\hline 1. & 600 & 618.72 & 103.12 & 1.03 \\
\hline 2. & 600 & 611.44 & 101.91 & \\
\hline 3. & 600 & 624.12 & 104.02 & \\
\hline
\end{tabular}

Labeled amount was the amount claimed by the manufacturer and estimated amount was the amount assayed through developed method 
Table 9: Summary of validation studies

\begin{tabular}{ll}
\hline Parameters (units) & Results \\
\hline Linearity & \\
range $(\mu \mathrm{g} / \mathrm{mL})$ & $1-9 \mu \mathrm{g} / \mathrm{mL}$ \\
Regression coefficient & $0.999 \pm 0.000577$ \\
Slope & $0.110 \pm 0.000577$ \\
Intercept & $+0.006 \pm 0.004041$ \\
Recovery (\%RSD) & \\
$75 \%$ spiking & 1.555 \\
$100 \%$ spiking & 1.596 \\
$125 \%$ spiking & 1.568 \\
Intra-day precision (\%RSD) (n=6) & 1.009 \\
$4 \mu \mathrm{g} / \mathrm{mL}$ & 1.267 \\
$6 \mu \mathrm{g} / \mathrm{mL}$ & 0.930 \\
$8 \mu \mathrm{g} / \mathrm{mL}$ & \\
Inter-day precision (\%RSD) (n = 3) & 1.271 \\
$4 \mu \mathrm{g} / \mathrm{mL}$ & 1.066 \\
$6 \mu \mathrm{g} / \mathrm{mL}$ & 1.311 \\
$8 \mu \mathrm{g} / \mathrm{mL}$ & 1.143 \\
Repeatability $(\% \mathrm{RSD})$ & 0.954 \\
Estimation of drug in bulk $(\% \mathrm{RSD})$ & 1.487 \\
\hline
\end{tabular}

the concentration range of 1 to $9 \mu \mathrm{g} / \mathrm{mL}$. Higher value of regression coefficient $(0.999 \pm 0.000577)$ confirmed the excellent linearity in the given range (1 to $9 \mu \mathrm{g} / \mathrm{mL}$ ) of prulifloxacin in SIF. For recovery studies, the lower values $(<2)$ of $\%$ RSD equal to $1.547,1.60$ and 1.584 for 75,100 and $125 \%$ spiking respectively indicate the accuracy of the developed method. For intraday and interday studies for preciseness, \% RSD values were lesser than $2 \%$ which confirmed preciseness and reliability of developed method. Again low value of \%RSD $<2$ ascertained the ruggedness of the developed method. It can be used by different analysts with confidence for a sufficient level of reliability. Repeatability of the proposed method was confirmed by low value of \%RSD $(<2)$.

The percentage RSD less than $2 \%$ proved that this method may also be used with confidence for estimating contents of prulifloxacin in the bulk. Using proposed method, contents of prulifloxacin in marketed tablets were found to be in sufficient accord with those of the claimed amounts and the $\%$ RSD value, found to be $1.03 \%$, is far $<2$, confirms that the proposed method can also be used with confidence for estimating the contents of prulifloxacin in tablet dosage forms. Results showed that excipients did not produce any interference in estimation of drug contents in tablets by proposed method.
In present study, summation of the obtained results inferred that the devised UV-spectroscopic method is an accurate yet simple, economic, and rapid method of estimating contents of prulifloxacin in SIF as well as for quantification of prulifloxacin in bulk and pharmaceutical preparations, especially tablets. The \% RSD values for all the parameters were found to be less than $2 \%$ for the proposed method. Validation of the proposed method confirms its authenticity as an appropriate method for the routine quantification of prulifloxacin in bulk as well as formulations like tablets. It can also be used as quality control method for the formulations containing prulifloxacin.

\section{ACKNOWLEDGMENTS}

The author is thankful to his colleagues for their kind co-operation and help in performing present study. Author is also thankful to head of the department and other staff members for furnishing the desired set-up, equipments, chemicals and other facilities as well as help sought to accomplish the presented piece of research.

\section{REFERENCES}

1. Martindale, 36th ed. Pharmaceutical Press, London, 2007, pp. 286.

2. The Merck Index, 14th ed. Merck and co. Inc, White House Station, New Jercy, 2004, pp. 7908.

3. Yoshida Y, Mitsuhashi S. Antibacterial activity of NM394, the active form of prodrug NM441, a new quinolone. Antimicrob Agents Chemother. 1993;37:793-800.

4. Ozaki M, Matsuda M, Tomii Y, Kimura K, Segawa J, Kitano M, Kise M, Shibata K, Otsuki M, Nishino T. In vivo evaluation of NM441, a new thiazeto-quinoline derivative.Antimicrob Agents Chemother. 1991;35:2496-2499.

5. Hooper DC, Wolfson JS. Mechanisms of quinolone action and bacterial killing. In: Quinolone antimicrobial agents, 2 nd ed. Washington D. C., American society for microbiology. 1993;pp. 53.

6. Hooper DC. Mode of action of fluoroquinolones, Drugs. 1999;58:6.

7. Panchumarthy R. Five novel spectrophotometric methods for quantitative determination of Prulifloxacin in pure and pharmaceutical formulations. Asian Journal of Biomedical and Pharmaceutical Sciences. 2015:1-13.

8. Purnima H, Patil P, Phale M, Sharma A. Development and Validation of a Stability-Indicating Assay (HPLC) Method for quantitative analysis of Prulifloxacin in Bulk Drug. Journal of Innovations in Pharmaceutical and Biological Sciences. 2015;2(3):300-311.

9. Singh RM, Singh S, Singh UK, Singh GN, Mathur SC, Saini PK, Yadav A, Gupta V, Duggal D. Development and validation of a RP-HPLC method for estimation of prulifloxacin in tablet dosage form. Indian J Pharm Sci. 2011;73(5):577-579.

10. Klein Sandra. The use of biorelevant dissolution media to forecast in-vivo performance of a drug. AAPS journal. 2010 Sep;12(3): 397406.

11. United States Pharmacopeia. USP 24. Rockville MD: USP Convention, Inc.; 2002.

12. ICH-Guidelines Q2 (R1), Validation of Analytical Procedures: Text and Methodology. 2005.

13. ICH (Q2, R1). Note for guidance on validation of analytical methods: Definitions and terminology. International conference on harmonization. 1994:9-13. 